\title{
ANALISIS SOSIAL EKONOMI BUDIDAYA UDANG GALAH (Macrobrachium rosenbergii) DI KABUPATEN GIANYAR, BALI
}

\author{
Sonny Koeshendrajana"), Dinarwan"*) dan Dicki Susanto")
}

\begin{abstract}
ABSTRAK
Riset sosial ekonomi budidaya udang galah (Macrobrachium rosenbergii) telah dilakukan pada bulan Mei sampai dengan Agustus 2001 di Kabupaten Gianyar, Propinsi Bali. Permasalahan umum yang dihadapi oleh pembudidaya maupun calon investor udang galah adalah belum adanya data dan informasi berkaitan dengan aspek teknis dan sosial ekonomi usaha. Penelitian dilakukan dengan menggunakan studi kasus; sedangkan pengambilan data dilakukan dengan sengaja (purposive sampling) di lokasi sentra produksi udang galah. Hasil riset menunjukkan bahwa kegiatan usaha budidaya udang galah di Kabupaten Gianyar, Propinsi Bali masih bersifat tradisional hingga semi intensif dan mempunyai pola usaha monokultur. Usaha budidaya dilakukan oleh pembudidaya yang termasuk dalam kelompok umur produktif; namun demikian, tingkat pendidikan maupun pengalaman berusaha mereka relatif rendah. Hasil analisis pengelompokkan responden pembudidaya menunjukkan tidak beda nyata, memberikan petunjuk bahwa pembudidaya udang galah di Kabupaten Gianyar tergolong dalam satu kelompok usaha.
\end{abstract}

\section{ABSTRACT: Social and Economic Analysis of Giant Prawn (Macrobrachium rosenbergii) Culture in Gianyar Region. By: Sonny Koeshendrajana, Dinarwan and Dicki Susanto.}

Social and economic research on giant prawn (Macrobrachium rosenbergii) has been carried out during the period of May-August 2001 in the Gianyar region of Bali province. Problems faced by fish farmers as well as investors of the giant prawn were dealing with the availability of data and information on technological and social economic aspects technological \& social economic aspect of its culture. Case study was used in the research while purposive sampling was used in the collection of data and information on giant prawn from the central production site. Results show that giant prawn cultured in the Gianyar region of Bali province operated in the monoculture pattern and applied traditional to semiintensive level of technology. Fish farmers who are in the productive-age-group operated giant prawn culture; however, their educational level and culture experiences were relatively low. Result of grouping fish farmers' respondent into small and big farmer showed that they were not statistical analysis of significantly diferrent. This, in turn, indicates that giant prawn farmers in Gianyar region should be classified in the same group.

KEYWORDS: $\quad$ social and economics, fish cultured, giant prawn

\section{PENDAHULUAN}

Udang galah (Macrobrachium rosenbergii) merupakan salah satu komoditas unggulan perikanan air tawar yang sangat potensial untuk dikembangkan. Budidaya udang galah ini sudah lama dikenal, namun perkembangannya terkesan sangat lamban. Selama ini produksi udang galah hanya mengandalkan dari kegiatan penangkapan di perairan umum terutama sungai; sedangkan dari kegiatan budidaya masih sangat kurang, sehingga pasokan udang galah tidak menentu. Kondisi ini menyebabkan para pengusaha cold storage maupun ekportir sering mengalami kekurangan bahan baku maupun produk udang galah. Fenomena tersebut memberikan kesempatan berkembangnya kegiatan usaha budidaya udang galah, khususnya bagi masyarakat pedesaan di sekitar daerah pemasaran tersebut.

Propinsi Bali selama ini memang lebih dikenal sebagai daerah tujuan wisata, namun saat ini juga mempunyai potensi sebagai daerah pengembangan usaha perikanan.

-) Peneliti pada Pusat Riset Pengolahan Produk dan Sosial Ekonomi Kelautan dan Perikanan

*) Dosen dan Alumnus pada Fakultas Perikanan dan Ilmu Kelautan, Institut Pertanian Bogor 
Posisi strategis yang ditunjang dengan keberadaan sarana dan prasarana yang memadai serta sumberdaya ikan yang tersedia saat ini merupakan modal yang berharga bagi Bali untuk mengembangkan usaha budidaya udang galah dalam upaya meningkatkan pendapatan masyarakat, daerah dan devisa negara

Sampai akhir tahun 2001, luas areal kolam udang galah yang ada di Kabupaten Gianyar lebih kurang 200 hektar dengan jumlah pembudidaya sebanyak 524 orang yang tergabung dalam 9 kelompok pembudidaya (Dinas Perikanan Kabupaten Gianyar, 1999; Dinas Perikanan Propinsi Bali, 1996-2001). Selain di Kabupaten Gianyar, usaha budidaya udang galah juga telah berkembang di Kabupaten Bangli, Badung, Buleleng, Tabanan, Klungkung, dan Karangasem. Disisi lain, terdapat peluang berupa kebutuhan udang galah ukuran konsumsi untuk kebutuhan hotel dan restoran, warung/rumah makan, dan pasar lokal ratarata $700 \mathrm{~kg}$ per hari atau sebesar 252 ton per tahun belum seluruhnya terpenuhi dari produksi di daerah Bali. Produksi benih udang galah di Bali sendiri baru bisa memenuhi 20\% dari seluruh permintaannya.

Pengelolaan kegiatan usaha budidaya udang galah di kabupaten Gianyar memiliki beberapa permasalahan. Permasalahan umum yang dihadapi oleh pembudidaya udang galah adalah berkaitan dengan aspek teknis, ekonomis maupun lingkungan sekitarnya (Koeshendrajana, 2001). Sejalan dengan perkembangan kegiatan usaha, permasalahan yang berkaitan dengan aspek tersebut semakin kompleks, antara lain, berkaitan dengan teknologi tepat guna, struktur kolam budidaya. Secara ekonomis permasalahan yang dijumpai adalah berkaitan dengan alokasi faktor produksi yang digunakan oleh pembudidaya serta aspek harga, baik faktor produksi maupun produk yang dihasilkan; sedangkan permasalahan lingkungan berkaitan dengan kondisi perairan dan kualitas air. Pada makalah ini, fokus analisis diarahkan pada aspek sosial ekonomi usaha dengan sedikit ilustrasi berkaitan dengan aspek teknik budidaya yang biasa diterapkan.

Penelitian ini bertujuan untuk mengetahui gambaran pola pengelolaan usaha budidaya udang galah di Kabupaten Gianyar Propinsi Bali; khususnya berkaitan dengan aspek teknis budidaya maupun sosial ekonomi usaha.

\section{METODE}

\section{Kerangka Pendekatan dan Ruang Lingkup}

Produksi udang galah di Kabupaten Gianyar mengalami peningkatan dari tahun ke tahun. Usaha produksi tersebut dilakukan oleh pembudidaya dalam jumlah relatif besar dengan pemilikan luasan kolam yang bervariasi. Luasan kolam yang bervariasi ini sangat memungkinkan timbulnya keragaan input-output yang bervariasi. Perbedaan skala luasan kolam tersebut diduga membedakan pola pengelolaan dan tingkat pendapatan usaha budidaya yang dilakukan. Untuk mengetahui adanya perbedaan tersebut, maka dilakukan analisis pendapatan usaha, analisis imbangan dan biaya; setelah itu dilakukan uji beda nyata terhadap komponen-komponen yang berpengaruh terhadap kegiatan budidaya udang galah. Selanjutnya berdasarkan hasil analisis dan uji beda nyata tersebut diduga dapat diketahui gambaran pola pengelolaan budidaya ini. Untuk lebih jelasnya, kerangka pendekatan studi ini dapat dilihat pada Gambar 1.

\section{Data dan Sumber Data}

Data primer dan data sekunder digunakan dalam penelitian ini. Data primer diperoleh dari hasil pengamatan dan wawancara secara langsung dengan pembudidaya udang galah dengan berpedoman pada kuesioner yang telah dipersiapkan, seperti karakteristik responden (antara lain: nama, umur, pendidikan dan pengalaman berusaha), penggunaan input produksi (antara lain: jumlah benur, jumlah pakan dan tenaga kerja) dan hasil panen selama satu musim produksi.

Data sekunder berupa data mengenai keadaan umum daerah penelitian beserta potensi perikanannya yang diperoleh dari berbagai instansi yang terkait, seperti Departemen Kelautan dan Perikanan Propinsi Bali, Badan Pusat Statistik Propinsi Bali dan lembaga lain yang terkait.

\section{Metode Pengumpulan Data}

Metode penelitian yang digunakan adalah studi kasus (case study). Studi kasus adalah suatu strategi penelitian multi-metode, yang 


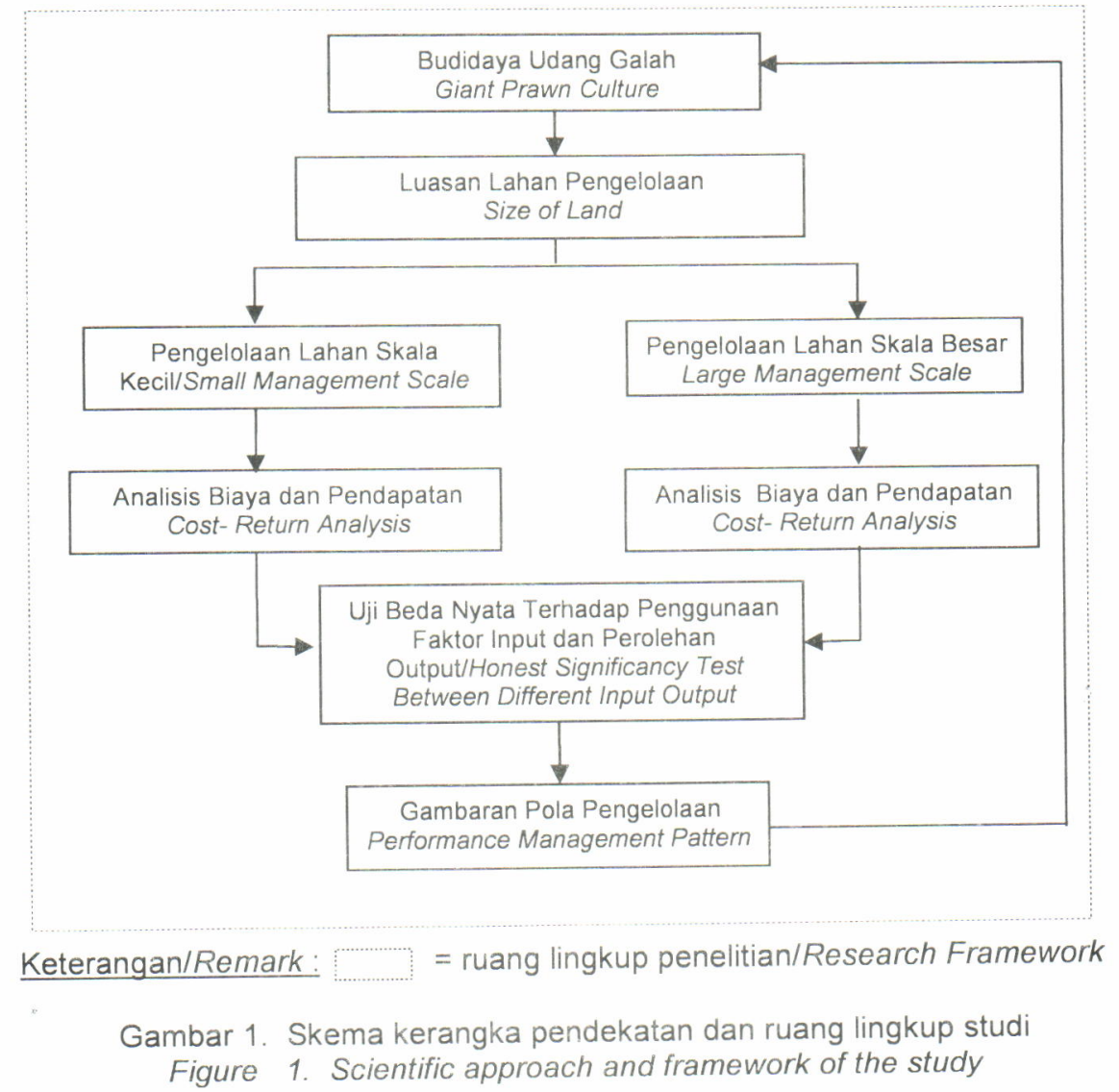

lazimnya memadukan teknik pengamatan, wawancara dan analisis dokumen (Sitorus, 1998; Daniel, 2002). Kasus yang dihadapi adalah kegiatan usaha pembesaran budidaya udang galah di Kabupaten Gianyar Propinsi Bali.

Pengambilan sampel dilakukan dengan menggunakan teknik 'purposive sampling', dimana sampel ditentukan berdasarkan kriteria-kriteria tertentu (Sugiyono, 2002). Kriteria tersebut, antara lain: pembudidaya udang galah yang terdapat di Kabupaten Gianyar dan pembudidaya tersebut melakukan kegiatan pemeliharaan udang galah mulai dari tahap penebaran sampai pemanenan.

Pengelompokan skala usaha pengelolaan budidaya udang galah dilakukan berdasarkan luasan lahan yang dimiliki oleh responden pembudidaya. Dalam hal ini, luasan lahan dikelompokkan menjadi dua kelompok, yaitu lahan skala kecil dan lahan skala besar. Pengelompokan pembudidaya ke dalam lahan skala kecil dan lahan skala besar ditentukan berdasarkan rataan luas lahan yang mereka gunakan.

\section{Metode Analisis}

Ánalisis deskriptif dan tabulasi silang dilakukan terhadap data kualitatif dan kuantitatif yang mencerminkan keragaan teknik budidaya dan sosial ekonomi usaha budidaya udang galah di Kabupaten Gianyar. Analisis pendapatan digunakan untuk mengetahui komponen-komponen input dan output yang terlibat dalam usaha yang dilakukan selama satu musim tanam dengan rumus (Soekartawi, 1995;2001):

$$
\Pi=\mathrm{TR}-\mathrm{TC}
$$

dimana

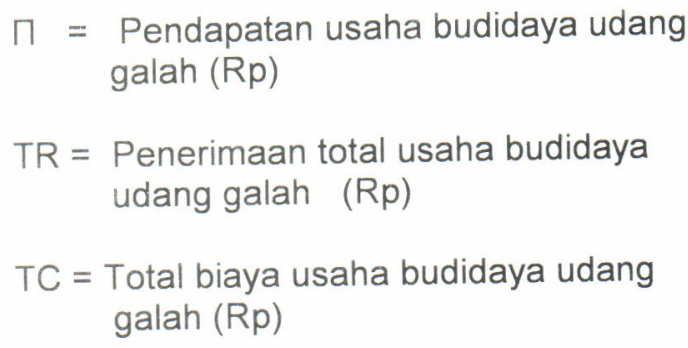
$\mathrm{TC}=$ Total biaya usaha budidaya udang galah (Rp)

Analisis Rasio Pendapatan dan Biaya digunakan untuk mengetahui sejauh mana 
hasil yang diperoleh dari kegiatan usaha selama satu masa pemeliharaan cukup menguntungkan, dengan menggunakan rumus:

\section{R/C Ratio $=\mathrm{TR} / \mathrm{TC}$}

dimana :

$$
\begin{aligned}
\text { TR = } & \text { penerimaan usaha budidaya } \\
& \text { udang galah } \\
\text { TC = } & \text { biaya usaha budidaya udang } \\
& \text { galah }
\end{aligned}
$$

Kriteria usaha yang digunakan adalah:

$\mathrm{R} / \mathrm{C}>1$, maka usaha untung

$\mathrm{R} / \mathrm{C}<1$, maka usaha rugi

$\mathrm{R} / \mathrm{C}=1$, maka usaha impas

Uji beda nyata terhadap faktor input dan output digunakan untuk menentukan apakah ada persamaan atau perbedaan antara faktor produksi atau input dan output kelompok pembudidaya lahan skala kecil dan lahan skala besar (Siegel, 1992; Sugiyono, 2002) untuk pengelolaan lahan skala kecil dan pengelolaan lahan skala besar dalam budidaya udang galah di Kabupaten Gianyar. Dugaan yang digunakan adalah sebagai berikut : $H_{0}=$ tidak terdapat hubungan yang nyata antara variabel input atau output pengelolaan lahan skala kecil dengan variabel input atau output pengelolaan lahan skala besar. $H_{1}=$ terdapat hubungan yang nyata antara variabel input atau output pengelolaan lahan skala kecil dengan variabel input atau output pengelolaan lahan skala besar. Hipotesis yang digunakan adalah sebagai berikut :

$$
\begin{aligned}
& H_{0}: x_{1}=x_{2} \\
& H_{1}: x_{1} \neq x_{2}
\end{aligned}
$$

Analisis yang digunakan pada uji beda nyata ini adalah uji t.

\section{HASIL DAN PEMBAHASAN}

\section{Teknik Budidaya Udang galah}

Budidaya udang galah yang dilakukan oleh responden pembudidaya udangdi Kabupaten Gianyar Propinsi Bali menggunakan pola monokultur dengan penggunaan tingkat teknologi bersifat tradisional hingga semi intensif. Penerapan tingkat teknologi bersifat tradisional dicirikan oleh penggunaan faktor produksi yang hanya mengandalkan penebaran benur dan tenaga kerja pembudidaya itu sendiri; sedangkan tingkat teknologi bersifat semi-intensif ditunjukkan oleh pembudidaya yang menggunakan faktor produksi pakan, pupuk dan faktor produksi jenis lainnya dalam menjalankan kegiatan usahanya (Panayotou et al., 1982; Edwards, 1993 and Tacon, 1997). Sarana untuk kegiatan usaha budidaya udang galah ini yaitu kolam dengan bentuk petakan teratur, bujur sangkar atau empat persegi panjang, mempunyai bentuk dasar kolam miring ke arah pintu pembuangan air. Detail operasional budidaya udang galah yang dilakukan oleh pembudidaya adalah sebagai berikut.

Lahan yang digunakan oleh pembudidaya udang galah di Kabupaten Gianyar sebagian besar merupakan lahan sawah dengan topografi landai dengan jenis tanah liat berpasir yang cukup mengandung humus. Kolam yang digunakan untuk budidaya ini sebagian berukuran relatif kecil yaitu 1-15 are per petak dengan kedalaman air berkisar antara 50-100 cm dan lebar pematang kurang lebih 1 meter. Air yang dimanfaatkan untuk budidaya udang galah bersumber dari air sungai dan saluran irigasi yang mengalir secara kontinu (terus menerus) selama masa pemeliharaan, tanpa pencemaran dan debit air 1 liter per detik per are per kolam.

Persiapan kolam yang biasa dilakukan oleh pembudidaya meliputi: (1) pengeringan, perbaikan kolam dan pengolahan tanah dasar kolam; (2) pengapuran dan pemupukan, serta; (3) pemasangan pelindung dengan menggunakan pelepah daun kelapa. Pengeringan dan perbaikan kolam umumnya dilakukan secara bersamaan, yakni sesudah dipanen dan menjelang musim tanam baru. Pengeringan dilakukan dengan cara menjemur dasar kolam yang akan digunakan sampai tanah menjadi retak-retak, kemudian tanah dasar kolam diolah dengan melakukan pencangkulan pada lapisan dasar dengan tujuan memperbaiki kondisi tanah atau memberantas hama serta penyakit. Tujuan dari pengeringan kolam adalah untuk menguraikan senyawa-senyawa sulfida dan senyawa beracun lain akibat dari proses perendaman selama musim tanam berlangsung. Selain itu, pengeringan kolam juga untuk memberi kesempatan terjadinya pertukaran udara. Dengan demikian dasar kolam kembali beroksigen, sehingga memungkinkan terjadinya proses mineralisasi, sekaligus memberantas benih-benih ikan liar yang merugikan kehidupan udang galah. Pengapuran dilakukan dengan tujuan agar 
keasaman tanah dasar dapat dikurangi. Jumlah kapur yang diberikan oleh pembudidaya kurang lebih $50 \mathrm{gr} / \mathrm{m}^{2}$. Pemberian pupuk dilakukan dengan menebarkan pupuk jenis Urea dan TSP (triple superfosfat). Pemupukan ini dilakukan untuk merangsang pertumbuhan makanan alami, terutama plankton nabati. Pupuk urea merupakan sumber nitrogen, sedangkan pupuk TSP merupakan sumber fosfat, dan penggunaan pupuk urea $20-30 \mathrm{gr} / \mathrm{m}^{2}$ sedangkan penggunaan TSP $30-40 \mathrm{gr} / \mathrm{m}^{2}$.

Setelah persiapan kolam dilakukan, kolam digenangi dengan air sampai setinggi $30 \mathrm{~cm}$. Setelah 3-4 hari, genangan air dinaikkan menjadi $50-60 \mathrm{~cm}$. Kemudian, kolam diberi pelidung berupa pelepah daun kelapa yang diletakkan di dasar kolam. Penebaran benih udang galah (benur PL 20-30) biasanya dilaksanakan pada pagi atau sore hari dengan aklimatisasi (penyesuaian suhu) selama kurang lebih 15 menit. Aklimatisasi dilakukan dengan cara mengapungkan kantong plastik yang berisi benur selama kurang lebih 15 menit agar suhu air dalam wadah kantong plastik dan di kolam menjadi sama. Setelah itu kantong plastik dibuka didalam kolam pembesaran. Tahap selanjutnya, benur dibiarkan keluar dari kantong plastik/wadah masuk ke kolam pembesaran. Penyesuaian suhu dilakukan untuk menghindari stress akibat perbedaan suhu air media, akibat proses pengangkutan dengan air kolam (Hadi dan Supriatna, 1991). Padat penebaran benur 10-20 ekor per $\mathrm{m}^{2}$, ukuran panjang benur $1-1,5 \mathrm{~cm}$ dan berat $0,01-0,015 \mathrm{gr} / \mathrm{ekor}$ dengan SR (survival rate) $50 \%$. Benur untuk budidaya udang galah di Propinsi Bali khususnya di Kabupaten Gianyar sebagian besar berasal dari Balai Benih Udang Galah (BBUG) di Kabupaten Klungkung, dan Balai Benih Udang galah (BBUG) Samas Yogyakarta. Pengangkutan benur dari Yogyakarta ke Bali biasanya menggunakan pesawat terbang walaupun terkadang menggunakan transportasi darat.

Pakan yang diberikan untuk udang galah berupa pakan buatan (pellet). Pada umumnya pemberian pakan dilakukan dalam 2 kali sehari yaitu $1 / 3$ bagian pada pagi hari dan $2 / 3$ bagian pada sore hari. Pakan diberikan sebanyak 250-500 gram per minggu. Pakan yang diberikan pada sore hari lebih banyak karena udang galah secara aktif mencari makan pada malam hari (nocturnal) (Sigit, 1986). Umumnya pembudidaya udang galah memakai 4 macam pellet sebagai pakan udang galah yaitu Comfeed, Bintang, UG, dan $S G H$. Jenis makanan tambahan yang diberikan pembudidaya berupa bekicot/keong sawah, umbi-umbian dan limbah sisa dapur (sisa makanan rumah).

Perawatan yang dilakukan oleh pembudidaya adalah mengamati dan memonitor kualitas air kolam. Pengontrolan saluran dan saringan air dilakukan agar aliran air tetap baik tanpa ada ikan liar yang terbawa aliran air seperti ikan gabus, ikan gurami atau ikan nila.

Secara umum dikenal 2 macam sistem pemeliharaan udang galah, yakni sistem pemeliharaan tetap dan pemeliharaan selektif. Sistem tetap adalah pemeliharaan udang galah menggunakan satu kolam untuk budidaya mulai penebaran benur dan dipelihara sampai panen selama 6 bulan. Sistem selektif adalah pemeliharan udang galah menggunakan lebih banyak petak kolam (lebih dari 2 kolam) karena adanya sortir/seleksi dalam budidaya. Setelah penebaran benur dilakukan pada kolam pertama, pada 2 bulan masa pemeliharaan dilakukan seleksi untuk memilih udang galah yang lebih besar untuk dipindahkan ke kolam lain (kolam kedua); sedangkan sisanya tetap pada kolam awal (kolam ke-1). Setelah mencapai 4 bulan masa pemeliharaan, udang galah yang ada di kolam kedua dilakukan pemanenan secara total. Udang galah pada pada kolam ke-1 dipanen dan diseleksi untuk dipindahkan ke kolam ke-2. kolam ke-1 dibiarkan untuk persiapan penebaran berikutnya. Panen total dilakukan setelah udangberumur 5-6 bulan. Pemanenan yang dilakukan biasanya langsung dibantu oleh pengumpul yang telah diberitahu sebelumnya oleh pembudidaya.

Pembudidaya udang galah di Kabupaten Gianyar dalam mengelola usahanya pada umumnya dikerjakan sendiri atau dibantu oleh anggota keluarganya, baik pada tahap pembuatan kolam, pemberian pakan maupun perawatan kolam. Hanya 7 orang pembudidaya responden yang menggunakan jasa orang lain untuk pembuatan kolam budidaya udang galah dengan imbalan $\mathrm{Rp}$ 25.000,- sampai Rp 30.000,- per orang per hari. Pembuatan kolam ini selesai setelah 3-4 hari.

Pemanenan udang galah umumnya dibantu oleh pedagang pengumpul yang datang setelah diberitahu pembudidaya dan juga keluarga pembudidaya seperti istri dan 
anaknya. Dalam pemanenan ini pembudidaya tidak membayar upah kepada pedagang pengumpul tersebut.

\section{Sosial Ekonomi Budidaya Udang Galah}

Pada penelitian ini, keragaan sosial ekonomi pembudidaya udang galah yang dimaksudkan mencakup aspek sosial ekonomi dan aspek finansial usaha. Aspek sosial ekonomi yang dimaksud adalah: umur, pengalaman usaha, pendidikan, tanggungan keluarga dan status responden.

\section{Aspek Sosial Ekonomi}

Pembudidaya udang galah yang menjadi responden dalam penelitian ini berjumlah 39 orang, yang terdiri dari 38 orang responden laki-laki $(97,44 \%)$ dan seorang responden perempuan (2,56\%). Pembudidaya udang galah baik pada lahan skala kecil maupun lahan skala besar masih tergolong ke dalam usia produktif, sebagian besar berumur sekitar 31-40 tahun dan 41-50 tahun dengan prosentase masing-masing sebesar 37,14\% dan 50 \%. Pengalaman usaha budidaya udang galah yang dimiliki oleh pembudidaya responden baik pengelolaan lahan skala kecil maupun skala besar sebagian besar berkisar antara 1 sampai 3 tahun. Hal ini diduga karena pada tahun 1997 harga udang galah mengalami peningkatan hingga mencapai $\mathrm{Rp}$ 70.000,- per kg, sehingga banyak pembudidaya yang sebelumnya merupakan pengelola lahan kolam untuk budidaya ikan karper, ikan nila maupun ikan mujair menjadi tertarik untuk membudidayakan udang galah

Gambaran sebaran umur dan pengalaman usaha responden pembudidayaan udang galah Kabupaten Gianyar Propinsi Bali dapat dilihat pada Tabel 1 dan Tabel 2 .

Tingkat pendidikan yang dicapai oleh pembudidaya udang galah merupakan salah satu faktor yang dapat mempengaruhi tingkat kemampuan kerja pembudidaya dalam menjalankan kegiatan usahanya. Lebih lanjut, tingkat pendidikan tersebut diduga akan mempengaruhi kemampuan pembudidaya

Tabel 1. Sebaran Umur Responden Pembudidaya Udang Galah di Kabupaten Gianyar, tahun 2001

Table 1. Age distribution of giant prawn farmers' respondent in Gianyar region, 2001

\begin{tabular}{ccccc}
\hline \multirow{2}{*}{\begin{tabular}{c} 
Sebaran Umur $\begin{array}{c}\text { (Tahun) } \\
\text { Age Distribution (Yr) }\end{array}$ \\
\cline { 2 - 5 }
\end{tabular}} & \multicolumn{3}{c}{ Skala Pengelolaan Lahan/Management Scale } \\
\cline { 2 - 5 } & $\begin{array}{c}\text { Jumlah/Number } \\
\text { (orang/person) }\end{array}$ & $\%$ & $\begin{array}{c}\text { Jumlah/Number } \\
\text { (orang/person) }\end{array}$ & $\%$ \\
\hline$<20$ & 1 & 2,86 & - & - \\
$21-30$ & 7 & 20 & 1 & 25 \\
$31-40$ & 13 & 37,14 & 2 & 50 \\
$41-50$ & 9 & 25,71 & 1 & 25 \\
$51-60$ & 5 & 14,29 & & \\
$>60$ & - & - & & 100 \\
\hline Jumlah/Total & 35 & 100 & 4 &
\end{tabular}

Tabel 2. Pengalaman Usaha Responden Pembudidaya Udang Galah di Kabupaten Gianyar, tahun 2001.

Table 2. Culture experience's of giant prawn farmers's respondent in Gianyar region, 2001

\begin{tabular}{ccccc}
\hline Pengalaman Usaha & \multicolumn{3}{c}{ Skala Pengelolaan Lahan/Management Scale } \\
\cline { 2 - 5 } & \multicolumn{2}{c}{ Kecil/Small } & \multicolumn{3}{c}{ Besar/Large } \\
\cline { 2 - 5 } & $\begin{array}{c}\text { Jumlah/Number } \\
\text { (Orang/Person) }\end{array}$ & $\%$ & $\begin{array}{c}\text { Jumlah/Number } \\
\text { (Orang/Person) }\end{array}$ & $\%$ \\
\hline $1-3$ & 16 & 45,71 & 3 & 75 \\
$4-6$ & 12 & 34,29 & 1 & 25 \\
$7-9$ & - & - & - & - \\
$10-12$ & 6 & 17,14 & - & - \\
$13-15$ & 1 & 2,86 & - & - \\
$>15$ & - & - & - & 100 \\
\hline Jumlah/Total & 35 & 100 & 4 & \\
\hline Sumber/Source: Data primer, diolah (Primary data) &
\end{tabular}


untuk menyerap pengetahuan dan keterampilan yang dianjurkan oleh Petugas Penyuluh Lapang (PPL). Pada pengelolaan lahan skala kecil, mayoritas responden pembudidaya udang galah memiliki tingkat pendidikan hanya sampai SD (65,72\%) sedangkan yang tidak sekolah hanya $5,71 \%$. Pada pengelolaan lahan skala besar, $50 \%$ pendidikannya hanya sampai SD. Tingkat pendidikan pembudidaya udang responden dapat dilihat pada Tabel 3 . tersedianya potensi tenaga kerja dalam menjalankan kegiatan budidaya udang galah tersebut.

Pada Tabel 4 dapat dilihat jumlah keluarga pembudidaya udang reponden di Kabupaten Gianyar baik pengelolaan lahan skala kecil maupun pengelolaan lahan skala besar. Pada kelompok responden pengelola lahan skala kecil, sebanyak 6 orang pembudidaya memiliki jumlah anggota keluarga antara 1-2

Tabel 3. Tingkat Pendidikan Responden Pembudidaya Udang Galah di Kabupaten Gianyar, tahun 2001

Table 3. Educational background of giant prawn farmers's respondent in Gianyar region, 2001.

\begin{tabular}{|c|c|c|c|c|}
\hline \multirow{3}{*}{$\begin{array}{l}\text { Tingkat Pendidikan } \\
\text { Level Of Education }\end{array}$} & \multicolumn{4}{|c|}{$\begin{array}{c}\text { Skala Pengelolaan Lahan } \\
\text { Management Scale }\end{array}$} \\
\hline & \multicolumn{2}{|c|}{ Kecil/Small } & \multicolumn{2}{|c|}{ Besar/Large } \\
\hline & $\begin{array}{l}\text { Jumlah/Number } \\
\text { (Orang/Person) }\end{array}$ & $\%$ & $\begin{array}{l}\text { Jumlah/Number } \\
\text { (Orang/Person) }\end{array}$ & $\%$ \\
\hline Tidak Sekolah/No School & 2 & 5,71 & - & - \\
\hline SD/Elementary & 23 & 65,72 & 2 & 50 \\
\hline SLTPIPrimary high school & 3 & 8,57 & 1 & 25 \\
\hline SLTAVSecondary high school & 6 & 17,14 & 1 & 25 \\
\hline Perguruan Tinggi/University & 1 & 2,86 & & \\
\hline Jumlah/Total & 35 & 100 & 4 & 100 \\
\hline
\end{tabular}

Sumber/Source: Data primer, diolah (Primary data)

Tabel 4. Jumlah Anggota Keluarga Responden Pembudidaya Udang Galah di Kabupaten Gianyar, tahun 2001.

Table 4. Household size of giant prawn farmers's respondent in Gianyar region, 2001.

\begin{tabular}{|c|c|c|c|c|}
\hline \multirow[t]{3}{*}{$\begin{array}{l}\text { Anggota Keluarga/Household } \\
\text { Number (orang/person) }\end{array}$} & \multicolumn{4}{|c|}{$\begin{array}{c}\text { Skala Pengelolaan Lahan } \\
\text { Management Scale }\end{array}$} \\
\hline & \multicolumn{2}{|c|}{ Kecil/Small } & \multicolumn{2}{|c|}{ Besar/Large } \\
\hline & $\begin{array}{c}\text { Jumlah } \\
\text { Total }\end{array}$ & $\%$ & $\begin{array}{c}\text { Jumlah } \\
\text { Total }\end{array}$ & $\%$ \\
\hline $1-2$ & 6 & 17,14 & 1 & 25 \\
\hline $3-4$ & 11 & 31,43 & 3 & 75 \\
\hline $5-6$ & 15 & 42,86 & - & - \\
\hline $7-8$ & 3 & 8,57 & - & - \\
\hline$>8$ & - & - & - & - \\
\hline Jumlah/Total & 35 & 100 & 4 & 100 \\
\hline
\end{tabular}

Sumber/Source: Data primer, diolah (Primary data)

Jumlah anggota keluarga yang tersedia pada satu keluarga merupakan potensi tenaga kerja keluarga pembudidaya. Hal ini berdasarkan fakta dilapang yang menunjukkan bahwa proporsi responden pembudidaya udang galah yang menggunakan tenaga kerja dari luar keluarga relatif kecil, mayoritas mereka menggunakan tenaga kerja keluarga. Dengan demikian, dalam kasus kelompok pembudidaya udang galah di lokasi studi, adanya jumlah anggota keluarga yang besar memberikan indikasi
$(17,14 \%), 11$ orang pembudidaya memiliki anggota keluarga $3-4$ orang $(31,43 \%), 15$ orang pembudidaya mempunyai $5-6$ orang $(42,86 \%)$ dan $8,57 \%$ lainnya mempunyai anggota keluarga 7-8 orang. Pada kelompok responden pengelola lahan skala besar, sebanyak $75 \%$ pembudidaya mempunyai jumlah keluarga 3-4 orang; sedangkan 25\% pembudidaya memiliki jumlah tanggungan keluarga 1-2 orang. Dari segi kepemilikan lahan, pembudidaya udang galah di Kabupaten Gianyar dapat dibagi menjadi 2 
Tabel 5. Status Kepemilikan Usaha Responden Pembudidaya Udang Galah di KabupatenGianyar, tahun 2001

Table 5. Ownership status of giant prawn farmers's respondent in Gianyar region, 2001.

\begin{tabular}{lcccc}
\hline \multirow{2}{*}{$\begin{array}{c}\text { Status Usaha } \\
\text { Farmer's Status }\end{array}$} & \multicolumn{4}{c}{$\begin{array}{c}\text { Skala Pengelolaan Lahan } \\
\text { Management Scale }\end{array}$} \\
\cline { 2 - 5 } & \multicolumn{2}{c}{ Kecil/Small } & \multicolumn{2}{c}{ Besar/Large } \\
\cline { 2 - 5 } & $\begin{array}{c}\text { Jumlah } \\
\text { Total }\end{array}$ & $\%$ & $\begin{array}{c}\text { Jumlah } \\
\text { Total }\end{array}$ & $\%$ \\
\hline Pemilik/ Penggarap(Owner/worker) & 23 & 65,71 & 2 & 50 \\
Penyewa(Tenant) & 12 & 34,29 & 2 & 50 \\
\hline Jumlah/Total & 35 & 100 & 4 & 100 \\
\hline Sumber/Source: Data primer, diolah (Primary data) & & &
\end{tabular}

kelompok, yaitu pembudidaya udang pemilik penggarap dan pembudidaya udang penyewa. Pembudidaya udang pemilik penggarap adalah pembudidaya udang yang mempunyai kolam dan menjalankan kegiatan usaha budidaya sendiri atau menggunakan tenaga kerja dari dalam keluarga; sedangkan pembudidaya udang penyewa adalah pembudidaya udang yang menjalankan kegiatan usaha budidaya menggunakan kolam yang disewa dari pihak lain. Baik pembudidaya pemilik maupun pembudidaya penyewa dalam sistem pengelolaannya tidak memiliki perbedaan. Status kepemilikan usaha pembudidaya udang secara keseluruhan dapat dilihat pada Tabel 5 .

\section{Aspek Finansial Usaha}

Dalam menjalankan kegiatan usaha budidaya udang galah, pembudidaya udangmenginvestasikan sebagian dari modal yang dimiliknya pada pembelian alat-alat produksi. Pada penelitian ini, biaya investasi yang diperhitungkan adalah pembelian lahan dan biaya pengadaan peralatan yang dipergunakan pembudidaya selama kegiatan usaha berlangsung.
Alat-alat yang digunakan adalah pipa (3 inci, 4 inci, 5 inci, pipa L), dop, jaring kawat halus, jaring kawat kasar, ember, serokan, cangkul, sekop, dan keranjang. Besarnya biaya rata-rata untuk lahan dan peralatan dapat dilihat pada Tabel 6

Jumlah benur yang digunakan oleh pembudidaya udang galah pada setiap pemilikan kolam bervariasi sesuai dengan ukuran kolam yang dibudidayakan Pemakaian benur selama satu musim tanam baik untuk pengelolaan lahan skala kecil dan pengelolaan lahan skala besar dapat dilihat pada Tabel 7 ,

Jenis pakan yang digunakan oleh pembudidaya udang galah di desa ini untuk kegiatan budidaya udang galah adalah pakan buatan (pellet) dan pakan tambahan, yang digunakan oleh pembudidaya udang. Pakan buatan yang digunakan terdiri dari 4 merek pakan udang galah yaitu pakan komersial I, II, III dan IV.

Pemupukan dalam budidaya udang galah ini dilakukan untuk merangsang pertumbuhan makanan alami, terutama plankton nabati.

Pupuk yang diberikan oleh pembudidaya

Tabel 6. Rata-rata Investasi yang Diperlukan untuk Usaha Budidaya Udang Galah di Kabupaten Gianyar, tahun 2001

Table 6. Average investment required for operating giant prawn culture in Gianyar region, 2001

\begin{tabular}{|c|c|c|c|c|}
\hline \multirow{3}{*}{$\begin{array}{l}\text { Komponen } \\
\text { Component }\end{array}$} & \multicolumn{4}{|c|}{$\begin{array}{c}\begin{array}{c}\text { Skala Pengelolaan Lahan } \\
\text { Management Scale }\end{array} \\
\end{array}$} \\
\hline & \multicolumn{2}{|c|}{ Kecil/Small } & \multicolumn{2}{|c|}{ Besar/Large } \\
\hline & $\begin{array}{l}\text { Pemilik } \\
\text { (Owner) }\end{array}$ & $\begin{array}{c}\text { Sewa } \\
\text { (Rental Tax) }\end{array}$ & Pemilik (Owner) & $\begin{array}{c}\text { Sewa (Rental } \\
\text { Tax) }\end{array}$ \\
\hline Lahan (Land) & $114.782 .608,70$ & 0 & $287.500 .000,00$ & 0 \\
\hline $\begin{array}{l}\text { Peralatan(Equipment } \\
\text { and material) }\end{array}$ & $244.478,26$ & $249.583,33$ & $257.500,00$ & $238.000,00$ \\
\hline $\begin{array}{l}\text { Total Investasi(Total } \\
\text { investment) }\end{array}$ & $115.027 .086,96$ & $249.583,33$ & $287.757 .500,00$ & $238.000,00$ \\
\hline
\end{tabular}


udang galah adalah Urea dan TSP (triple superfosfat). Pupuk urea merupakan sumber nitrogen, dan pupuk TSP merupakan sumber fosfat. Pengapuran yang dilakukan oleh pembudidaya udang bertujuan untuk mengurangi keasaman tanah dasar kolam budidaya udang galah. Rata-rata pemakaian selama satu musim tanam pengelolaan lahan skala kecil dan pengelolaan lahan skala besar dapat dilihat pada Tabel 9.

Tenaga kerja untuk budidaya udang galah digunakan mulai dari kegiatan persiapan/ pembuatan kolam sampai kegiatan panen. Umumnya pembudidaya mengurus sendiri pengelolaan budidaya udang galah ini dan biasanya pada saat pembuatan kolam atau pada saat panen pengerjaannya dibantu oleh pihak lain, baik itu dari anggota keluarga atau kerabat sendiri atau orang lain diluar anggota keluarga pembudidaya. Pemberian upah untuk tenaga kerja didasarkan atas jumlah hari kerja dengan kisaran upah kelompok jenis kelamin yang sama maupun dalam kelompok jenis kelamin yang berbeda.

Ukuran yang biasanya diminta oleh konsumen atau pengumpul adalah size-30 (30 ekor dalam $1 \mathrm{~kg}$ atau berat udang galah mencapai 25 sampai 40 gram per ekor). Produksi dan penerimaan usaha budidaya Udang galah dapat dilihat pada Tabel 10.

Tabel 7. Rata-Rata Kebutuhan Benur Untuk Budidaya Udang Galah di Kabupaten Gianyar, tahun 2001.

Table 7. Average stocking of fry for operating giant prawn culture in Gianyar region, 2001.

\begin{tabular}{cccc}
\hline No & $\begin{array}{c}\text { Skala Pengelolaan Lahan } \\
\text { (Management Sca/e) }\end{array}$ & $\begin{array}{c}\text { Volume } \\
\text { (Ekor/Piece) }\end{array}$ & $\begin{array}{c}\text { Nilai (Value) } \\
\text { (Rp/IDR) }\end{array}$ \\
\hline 1 & Kecil/Small & 10.886 & $707.571,40$ \\
2 & Besar/Large & 17.000 & $1.105 .000,00$ \\
\hline \multicolumn{2}{l}{ Sumber/Source: Data primer, diolah (Primary data) }
\end{tabular}

Tabel 8. Penggunaan Pakan Udang Galah oleh Pembudidaya di Kabupaten Gianyar, tahun 2001.

Table 8. Giant prawn feed use by farmers in Gianyar Region, 2001.

\begin{tabular}{cccccc}
\hline \multirow{2}{*}{ No } & \multirow{2}{*}{$\begin{array}{c}\text { Komponen } \\
\text { Component }\end{array}$} & \multicolumn{3}{c}{ Skala Pengelolaan Lahan (management scale) } \\
\cline { 3 - 6 } & \multicolumn{2}{c}{ Kecil/Small } & \multicolumn{2}{c}{ Besar/Large } \\
\cline { 2 - 6 } & Rp(IDR) & $\%$ & Rp (IDR) & $\%$ \\
\hline 1 & $\begin{array}{l}\text { Pakan Komersial I } \\
\text { Commercial Feed I }\end{array}$ & $335.571,43$ & 30,07 & 675.000 & 48,65 \\
2 & $\begin{array}{l}\text { Pakan Komersial II } \\
\text { Commercial Feed II }\end{array}$ & $318.857,14$ & 28,57 & 581.250 & 41,89 \\
3 & $\begin{array}{l}\text { Pakan Komersial III } \\
\text { Commercial Feed III }\end{array}$ & $235.200,00$ & 21,08 & 131.250 & 9,46 \\
4 & $\begin{array}{l}\text { Pakan Komersial IV } \\
\text { Commercial Feed IV }\end{array}$ & $226.285,71$ & 20,28 & 0 & 0 \\
\hline & Total Pakan/Total Feed & $1.115 .914,28$ & 100 & 1.387 .50 & 100 \\
\hline
\end{tabular}

Sumber/Source: Data primer, diolah (Primary data)

Tabel 9. Pemakaian Rata-Rata Pupuk dan Kapur oleh Pembudidaya Udang Galah di Kabupaten Gianyar, tahun 2001

Table 9. Average fertilizer use by giant prawn farmers in Gianyar Region, 2001

\begin{tabular}{|c|c|c|c|c|c|}
\hline \multirow{3}{*}{ No } & \multirow{3}{*}{$\begin{array}{l}\text { Komponen } \\
\text { Component }\end{array}$} & \multicolumn{4}{|c|}{ Skala Pengelolaan Lahan (management scale) } \\
\hline & & \multicolumn{2}{|c|}{ Kecil/Small } & \multicolumn{2}{|c|}{ Besar/Large } \\
\hline & & Rp (IDR) & $\%$ & Rp (IDR) & $\%$ \\
\hline 1 & Urea & $5.871,43$ & 29,38 & $6.750,00$ & 31,76 \\
\hline 2 & TSP & $8.057,14$ & 40,31 & $9.500,00$ & 44,71 \\
\hline 3 & Kapur (lime) & $6.057,14$ & 30,31 & $5.000,00$ & 23,53 \\
\hline & Jumlah/Total & $19.985,71$ & 100 & $21.250,00$ & 100 \\
\hline
\end{tabular}

Sumber/Source: Data primer, diolah (Primary data) 
Secara keseluruhan jumlah produksi udang galah untuk pengelolaan lahan skala kecil selama satu musim tanam adalah $3.408 \mathrm{~kg}$ dengan rata-rata produksi $97,37 \mathrm{~kg}$ per petak kolam dan untuk pengelolaan lahan skala besar jumlah produksi sebesar $559 \mathrm{~kg}$ per petak kolam dengan rata-rata produksi 139,75 $\mathrm{kg}$ per petak kolam. Dengan harga udang galah sebesar Rp 43.000,- per kg maka jumlah yang diterima oleh pembudidaya selama satu musim tanam untuk pengelolaan lahan skala kecil dan pengelolaan lahan skala besar dapat dilihat pada Tabel 10.

Pada suatu kegiatan usaha budidaya yang bersifat komersil maka biaya usaha merupakan hal yang perlu diperhatikan,
Bali yang mahal. Untuk biaya variabel yang dikeluarkan pembudidaya udang galah lahan skala kecil, komponen terbesar terletak pada upah tenaga kerja. Hal ini diduga karena Propinsi Bali dikenal sebagai daerah wisata dunia sehingga biaya hidup tinggi, dan salah satu dampaknya adalah tingginya upah tenaga kerja. Pada budidaya udang galah dengan pengelolaan lahan skala besar pengeluaran biaya tertinggi terletak pada pembelian pakan. Hal ini karena pada pengelolaan lahan skala besar benur yang ditebar relatif lebih banyak sehingga biaya untuk pengeluaran pakan menjadi besar.

Pendapatan bersih usaha budidaya adalah selisih antara penerimaan dengan biaya total.

Tabel 10 Produksi dan Penerimaan Usaha Budidaya Udang Galah Di Kabupaten Gianyar, tahun 2001.

Table 10. Volume and value of production of giant prawn culture in Gianyar region, 2001.

\begin{tabular}{|c|c|c|c|c|}
\hline \multirow{3}{*}{$\begin{array}{l}\text { Uraian } \\
\text { Category }\end{array}$} & \multicolumn{4}{|c|}{$\begin{array}{c}\text { Skala Pengelolaan Lahan } \\
\text { Management Scale }\end{array}$} \\
\hline & \multicolumn{2}{|c|}{ Kecil/Small } & \multicolumn{2}{|c|}{ Besar/Large } \\
\hline & $\begin{array}{l}\text { Volume } \\
\text { (kg) }\end{array}$ & $\begin{array}{l}\text { Nilai (Value) } \\
\text { (Rp )(IDR) }\end{array}$ & $\begin{array}{l}\text { Volume } \\
(\mathrm{kg})\end{array}$ & $\begin{array}{l}\text { Nilai (Value) } \\
\text { (Rp) (IDR) }\end{array}$ \\
\hline Total/Total & 3408,00 & $146.544 .000,00$ & 559,00 & $24.037 .000,00$ \\
\hline Rata-rata/Average & 97,37 & $4.186 .971,43$ & 139,75 & $6.009 .250,00$ \\
\hline
\end{tabular}

karena untuk menghasilkan produk diperlukan biaya-biaya untuk mengolah input. Biaya usaha yang dikeluarkan oleh pembudidaya udang galah selama satu musim terdiri dari biaya tetap dan biaya variabel. Biaya tetap yang dikeluarkan oleh pembudidaya udang meliputi biaya sewa kolam, dan biaya irigasi (subak), biaya penyusutan peralatan seperti pipa (3,4 dan 5 inci, pipa $L$, dop, jaring kawat halus, jaring kawat kasar, ember, serok, cangkul, sekop dan keranjang). Biaya variabel yang dikeluarkan oleh pembudidaya udang selama satu musim tanam terdiri dari biaya untuk pembelian sarana produksi berupa benur, pakan, TSP, urea dan kapur serta biaya tenaga kerja. Biaya total merupakan jumlah dari biaya tetap dan biaya variabel. Jumlah rata-rata biaya total yang dikeluarkan oleh pembudidaya udang terlihat pada Tabel 11.

Komponen terbesar dari biaya tetap yang dikeluarkan oleh pembudidaya udang galah responden untuk pengelolaan lahan skala kecil maupun pengelolaan lahan skala besar adalah untuk menyewa lahan. Hal ini karena harga lahan di Kabupaten Gianyar Propinsi
Pada Tabel 12 dapat dilihat jumlah rata-rata pendapatan pembudidaya udang galah untuk satu musim tanam.

Berdasarkan hasil analisa yang dilakukan terlihat bahwa pembudidaya udang galah responden untuk pengelolaan lahan skala besar rata-rata memperoleh nilai penerimaan usaha Rp. 6.009.250,-; sedangkan untuk pengelolaan lahan skala kecil sebesar Rp. 4.186.971,42. Pendapatan usaha budidaya udang galah yang diperoleh oleh pembudidaya udang galah responden untuk pengelolaan lahan skala besar rata-rata $\mathrm{Rp}$ 1.611.125,- dan untuk pengelolaan lahan skala kecil sebesar Rp. 860.942,86. Hal ini karena total penerimaan usaha pembudidaya udang galah responden lebih besar dibandingkan dengan total biaya yang dikeluarkan.

Pembudidaya udang selalu mengharapkan keuntungan dari kegiatan usaha yang dilakukannya. Untuk mengetahui sejauh mana kegiatan usaha tersebut menguntungkan maka dilakukan analisis R/C Ratio.

Pembudidaya udang galah di Kabupaten 
Gianyar baik untuk pengelolaan lahan skala kecil maupun pengelolaan lahan skala besar dalam analisis usaha rata-rata mendapatkan keuntungan dalam menjalankan usahanya.

Untuk pengelolaan lahan skala kecil mempunyai R/C Ratio sebesar 1,27 ini berarti bahwa setiap Rp.1,- yang dikeluarkan pembudidaya udang dalam menjalankan usaha budidayanya akan menghasilkan penerimaan Rp.1,27,- Untuk pengelolaan lahan skala besar, R/C ratio yang diperoleh adalah sebesar 1,39 yang berarti bahwa setiap Rp.1,- yang dikeluarkan pembudidaya udang dalam menjalankan usaha budidayanya akan menghasilkan penerimaan $\mathrm{Rp}$. 1,39,- tingkat penerimaan memberikan petunjuk bahwa dalam hal pembudidaya udang galah di Kabupaten Gianyar pada hakekatnya tidak dapat dibedakan dalam kelompok usaha skala kecil dan kelompok usaha skala besar.

Hal ini dimungkinkan oleh kenyataan di lapang yang menunjukkan bahwa mereka relatif menggunakan tingkat teknologi yang sama, yaitu teknologi budidaya secara tradisional hingga semi-intensif.

\section{KESIMPULAN}

Kegiatan usaha pembesaran budidaya udang galah di Kabupaten Gianyar, Propinsi Bali masih bersifat tradisional hingga semi

Tabel 11. Jumlah Rata-Rata Biaya Tetap, Biaya Variabel dan Biaya Total Pembudidaya Udang Galah Di Kabupaten Gianyar, tahun 2001.

Table 11. Average fixed, variable and total cost of giant bprawn culture in Gianyar region, 2002.

\begin{tabular}{lcrrr}
\hline \multirow{2}{*}{$\begin{array}{c}\text { Uraian } \\
\text { Category }\end{array}$} & \multicolumn{3}{c}{$\begin{array}{c}\text { Skala Pengelolaan Lahan } \\
\text { Management Scale }\end{array}$} \\
\cline { 2 - 5 } & \multicolumn{1}{c}{ Kecil/Small } & \multicolumn{2}{c}{ Besar/Large } \\
\cline { 2 - 5 } & Rp (IDR) & $\%$ & \multicolumn{1}{c}{ Rp (IDR) } & $\%$ \\
\hline Biaya Tetap/Fixed cost & $346.700,00$ & 10,42 & $759.375,00$ & 17,27 \\
Biaya Variabel/Variable cost & $2.979 .328,57$ & 89,58 & $3.638 .750,00$ & 82,73 \\
Biaya Total/Total cost & $3.326 .028,57$ & 100 & $4.398 .125,00$ & 100 \\
\hline
\end{tabular}

Sumber/Source: Data primer, diolah (Primary data)

Tabel 12. Penerimaan, biaya total, pendapatan serta rasio penerimaan dan biaya total usaha budidaya udang galah di Kabupaten Gianyar, 2001

Table 12. Revenue, total cos, income and R/C ratio of giant prawn culture in Gianyar region, 2001

\begin{tabular}{lccrr}
\hline $\begin{array}{c}\text { Skala } \\
\text { Pengelolaan Lahan } \\
\text { (Management Scale) }\end{array}$ & $\begin{array}{c}\text { Penerimaan } \\
\text { (Revenue) }\end{array}$ & $\begin{array}{c}\text { Biaya Total } \\
\text { (Total Cost) }\end{array}$ & $\begin{array}{c}\text { Pendapatan } \\
\text { (Income) }\end{array}$ & $\begin{array}{c}\text { R/C } \\
\text { Ratio }\end{array}$ \\
\hline Kecil/Small & $4.186 .971,42$ & $3.326 .028,57$ & $860.942,86$ & 1,27 \\
Besar/Large & $6.009 .250,00$ & $4.398 .125,00$ & $1.611 .125,00$ & 1,39 \\
\hline
\end{tabular}

Sumber/Source: Data primer, diolah (Primary data)

Analisis Uji Beda Nyata Terhadap MasingMasing Input dan Output Produksi

Analisis pengujian beda nyata yang dilakukan untuk menguji apakah masingmasing input dan output produksi yang digunakan antara pengelolaan lahan skala kecil dan pengelolaan lahan skala besar tersebut sama atau berbeda secara nyata. Pengujian ini menggunakan uji $t$ dengan menggunakan program Minitab pada komputer. Hasil uji beda nyata ini secara rinci dapat dilihat pada Tabel 13. Hasil analisis yang menunjukkan tidak beda nyata baik pada penggunaan faktor produksi maupun intensif dan mempunyai pola usaha monokultur. Usaha budidaya dilakukan oleh pembudidaya yang termasuk dalam kelompok umur produktif; namun demikian, tingkat pendidikan maupun pengalaman berusaha mereka relatif rendah. Hasil analisis pengelompokkan responden pembudidaya menunjukkan tidak beda nyata, memberikan petunjuk bahwa berdasarkan klasifikasi luas lahan budidaya, pembudidaya udang galah di Kabupaten Gianyar tergolong dalam satu kelompok luas lahan budidaya.

Implikasi kebijakan yang dapat dirumuskan dalam studi ini adalah: 
Tabel 13. Analisis Uji Beda Nyata Terhadap Masing-Masing Input dan Output Produksi Usaha Budidaya Udang Galah di Kabupaten Gianyar, tahun 2001.

Table 13. Testing significancy of each production input and output of giant prawn culture in Gianyar region, 2001

\begin{tabular}{|c|c|c|c|c|c|}
\hline \multirow{2}{*}{$\begin{array}{c}\text { Uraian } \\
\text { (Description) }\end{array}$} & \multicolumn{2}{|c|}{ Mean } & \multicolumn{2}{|c|}{$\begin{array}{c}\text { Hasil Uji t } \\
\text { (t-test) }\end{array}$} & \multirow{2}{*}{ df } \\
\hline & $\begin{array}{c}\text { SPL Kecil } \\
\text { (Small) }\end{array}$ & $\begin{array}{c}\text { SPL Besar } \\
\text { (Large) }\end{array}$ & $\mathrm{t}$ & $\mathbf{p}$ & \\
\hline Benur (Fry) & 10.886 & 17000 & $-1,73^{*}$ & 0,18 & 3 \\
\hline Pakan (Feed) & 340 & 469 & $-2,29^{*}$ & 0,084 & 3 \\
\hline TK (Labour) & 158,1 & 168,8 & $-0,30^{*}$ & 0,79 & 3 \\
\hline Urea & 3,91 & 4,50 & $-0,26^{*}$ & 0,81 & 3 \\
\hline TSP & 4,03 & 4,75 & $-0,33^{*}$ & 0,76 & 3 \\
\hline Kapur (Lime) & 30,3 & 31,2 & $-0,14^{\star}$ & 0,89 & 3 \\
\hline Kedalaman (Depth) & 0,79 & 0,56 & $2,36^{*}$ & 0,10 & 3 \\
\hline Produksi (Production) & 97,4 & 139,8 & $-1,38^{*}$ & 0,26 & 3 \\
\hline Biaya Tetap (Fixed Cost) & 281043 & 506375 & $-1,22^{\star}$ & 0,31 & 3 \\
\hline Biaya Variabel (Variable Cost) & 2979329 & 3638750 & $-2,04^{*}$ & 0,13 & 3 \\
\hline Biaya Total (Total Cost) & 3326029 & 4398125 & $-2,15^{*}$ & 0,12 & 3 \\
\hline Pendapatan (Income) & 860943 & 1611125 & $-0,79^{*}$ & 0,48 & 3 \\
\hline $\begin{array}{l}\text { Keterangan/Remark: } \\
{ }^{*}=\text { tidak berbeda nyata/Non Sig } \\
\text { Nilai DF berdasarkan nilai } n \text { terk } \\
\text { sample } \\
\text { Tingkat kepercayaan/Leve/ Signi } \\
\text { Hipotesa/Hypothesis : } p \leq 0,05 \\
\text { Hipotesa/Hypothesis : } p \geq 0,05\end{array}$ & $\begin{array}{l}\text { Value of } L \\
(a)=0,05 \\
\text { eda nyata/S } \\
\text { berbeda ny }\end{array}$ & $\begin{array}{l}\text { depends on } \\
\text { nificant } \\
\text { a/Non Signific }\end{array}$ & smalle. & mber o & \\
\hline
\end{tabular}

(1). Pembudidaya masih menggunakan pola pengelolaan yang tradisional hingga semi-intensif; upaya optimalisasi pengelolaan usaha masih memungkinkan dilakukan melalui optimasi alokasi penggunaan input produksi yang digunakan.

(2). Pakan dan bibit merupakan komponen penting dalam struktur biaya produksi. Upaya optimalisasi usaha dapat dilakukan dengan memperkenalkan benih/benur varietas unggul, misalnya udang galah G-Macro, atau memperkenalkan jenis pakan udang yang lebih efisien dan ramah lingkungan.

(3). Kondisi sosial ekonomi pembudidaya udang galah di Kabupaten Gianyar secara implisit memberikan petunjuk bahwa optimalisasi pengelolaan usaha dapat dilakukan melalui kegiatan penyuluhan dan pembinaan kelompok; antara lain berkaitan dengan organisasi pengadaan sarana produksi dan pemasaran produk serta pengenalan paket-paket teknologi baru yang telah dihasilkan oleh institusi-institusi riset.

\section{UCAPAN TERIMA KASIH}

Ucapan terima kasih disampaikan terutama kepada Bapak Ketut Boleh, Sdr. Dicki Susanto, Sdr. Yosep Nirwana dan Sdr. Erlan Mulyana Kusumah atas bantuan dan kerjasama yang diberikan selama pengumpulan data dan informasi di lapang. Ucapan terima kasih juga penulis sampaikan kepada responden pembudidaya Udang galah di kabupaten Gianyar.

\section{DAFTAR PUSTAKA}

Daniel, M. 2002. Metode Penelitian Sosial Ekonomi Dilengkapi Beberapa Alat Analisa dan Penuntun Penggunaan. Penerbit Bumi Aksara . Jakarta. 166 hal

Dinas Perikanan Kabupaten Gianyar. 1999. Monografi Sektor Perikanan Kabupaten Gianyar Propinsi Bali.

Dinas Perikanan Propinsi Bali. 1996-2001. Laporan Tahunan Statistik Perikanan Propinsi Bali. 
Tahunan Dinas Perikanan Propinsi Bali

Edwards, P. 1993, 'Environmental issues in integrated agriculture-aquaculture and wastewater-fed fish culture systems', p. 139-70. In Pullin, R.S.V., Resenthal H. and Maclean, J.L. (eds.). Environmental and Aquaculture in Developing Countries. ICLARM Conf. Proc. 31, $159 p$.

Fauzi, A. 2001. Prinsip-Prinsip Penelitian Sosial Ekonomi: Panduan Singkat. Jurusan Sosial Ekomi Perikanan dan Kelautan. Institut Pertanian Bogor : $28 \mathrm{p}$

Hadi, W. dan Supriatna, J. 1991. Pengembangan Udang galah Dalam Hatchery dan Budidaya. Penerbit Kanesius. Jogyakarta. 124 p.

Koeshendrajana, S. 2001. 'Sistem Usaha Perikanan Budidaya Udang galah: Status, Permasalahan, Kendala dan Peluang Pengembangan', Jurnal Ilmu-ilmu Perairan dan Perikanan Indonesia (Edisi Khusus Crustacea), Vol 1 (2): 17-32.

Panayotou, T., Wattanutchariya, S., Isvilanonda S. and Tokrisna, R. 1982. 'The Economics Of Catfish Farming In Central Thailand', Kasetsart University Research and Development Institute, Bangkok, Thailand and International and Center for Living Aquatic Resource Management, manila, Philippines.

Siegel, S. 1992. Statistik Nonparametrik Untuk Ilmu-ilmu Sosial. PT. Gramedia, Jakarata. 374 p.

Sigit, S.W. 1986. Pemeliharaan Udang galah di Kolam Air Tawar. PT. Waca Utama. Pramesti dan Pemda DKI Jakarta. Jakarta. 147 p.

Sitorus, FMT. 1998. Penelitian Kualitatif Suatu Perkenalan. Fakultas Pertanian Institut Pertanian Bogor. 73 p.

Soekartawi.1995. Teori Ekonomi Produksi dengan Pokok Bahasan Analisis Fungsi CobbDouglass. Raja Gafindo Persada. Jakarta. 257 p. 2001. Agribisnis Teori dan Aplikasinya. Raja Gafindo Persada. Jakarta. 205 hal

Sugiyono. 2002. Statistika Untuk Penelitian. Penerbit Alfabeta. Bandung. 306 p.

Tacon, Albert G.J. 1997, 'Feeding tomorrow's fish: the asian perspective', p. 20-42. In Nambiar, KPP and Tarlochan Singh (eds.), Sustainable Aquaculture. Proceedings of INFOFISH AQUATECH '96. International Conference on Aquaculture, Kuala Lumpur, Malaysia, 25-27 September 1996. 
